\title{
The Role of Tea Farmer Group in Tea Smallholder Downstream Supply Chain Cooperatives in West Java Province, Indonesia
}

\section{Kralawi Sita1, Sunarru Samsi Hariadi², and Subejo²}

${ }^{1}$ Research Institute for Tea and Cinchona, Gambung, West Java, Indonesia 40972

${ }^{2}$ Graduate School Gadjah Mada University, Yongyakarta, Indonesia 55281

\section{Abstract}

West Java Province is the center of the largest tea producer in Indonesia, includes its tea smallholders. The existence of tea farmer groups as main actor on tea agribusiness plays important and strategic role in realizing sustainability business unit for tea smallholder downstream supply chain. This study aims to: (1) describes the role of tea farmer groups on tea smallholder downstream supply chain; 2) describes the development of tea smallholder downstream supply chain cooperatives. The main method of this study used a descriptive qualitative approach. Data was collected by in depth interview and focus group discussion (FGD). Data sources were analyzed by used analysis triangulation. The results shown that a few active tea farmer groups in West Java, can successful run the role of group as a business unit in downstream supply chain that has changed its member's behavior in tea selling activity, improved the member's income, improved the value added of tea smallholder product, improved the transfer of simple processing technology of tea production, encouraged the local tea product creation, improved tea promotion with government support, and built network in market. In develop sustainability tea supply chain cooperatives, tea farmer groups together joint in tea farmer group association (Gapoktan) to built own factory and village unit cooperative (Koperasi), built network and make a partnerships with government, private plantation, tea factories, and stores. The challenges of tea farmers groups in downstream supply chain are capital, tea prices, and policy that pro tea smallholder. So, sustainable assistance and extension to tea farmer groups important needed.

Keywords: role, tea farmer group, downstream, supply chain, cooperative.

\section{Introduction}

The growth of the market in global tea consumption demand continued to increase from year to year in line with world population growth which also continues to increase. The growth rate of global tea consumption in 2014 was $4.3 \%$ and is expected 
in 2015 was $5 \%$ [1]. However, the impact of the huge demand of global tea consumption are not yet to be fully felt directly by the people of the tea smallholders in Indonesia as the main actors and producers of tea which owns a $46 \%$ [2] of the total area of tea plantation in Indonesia. The problem lies on the tea marketing aspect in addition to limited access to market information, the mastery of technology, production inputs and capital. In generally tea smallholders still sell in the form of green leaf (GL) where the marketing chain are often not distributed equitably and shoots the price the farmer is still very low, that caused the low income of tea smallholders. This condition makes it increasingly weak and fragile of the tea smallholders bargaining position in the tea supply chain. So we need new approaches to respond.

One of strategy that can encourage the growth of people's participation in various development programs, especially the development of the tea plantations of the people is through a group approach. This strategy was developed in the highly prospective tea growers of the people through collective action together with the group in order to develop the tea farming more economically viable and competitive, so as to be aligned with tea actors sharing.

Group approach is considered more efficient and can be a medium for the process of learning and interaction of farmers, especially for tea smallholders, so expect a change in people's behavior tea farmers toward better or quality [3]. Tea farmer group grew and formed by initiative of tea communities itself has aims to solve the problems faced by the farming community as an individually and groups as an aggregate of tea smallholders. The group serves as the unit of learning, production units, cooperative units, and business units $[4,5]$. The existence of the tea farmer group is very important to advance tea smallholders communities because the tea farmer group can be a container of aspiration, inspiration, learning and cooperation to build networks and partnerships with members of other tea stakeholders in order to utilize the resources in order to encouraging and expanding downstream supply chain of tea smallholders product with the goal of increasing farm productivity tea and welfare of its members.

This study aims to describes the role of tea farmer groups on tea smallholder downstream supply chain and the development of tea smallholder downstream supply chain cooperatives.

\section{Materials and Method}

This research used descriptive qualitative approach to give a broad overview and in-depth study of the object to be studied [6]. This research held in three center of tea smallholder plantation in West Java as the biggest tea producer in Indonesia, i.e. Sukabumi, Tasikmalaya, dan Purwakarta District on February to April 2015. Qualitative 
data collection was done by used observation, in-depth interviews, focus group discussions (FGD) and documentation. Informants of this research are farmer, tea farmer group, trader, local tea factory, and extension worker. Data was analyzed by used triangulation of data sources, through the major phases of data reduction, data display, and conclusion drawing and verification $[7,8]$.

\section{Results and Discussion}

Geographically, West Java Province located in between $5^{\circ} 50^{\prime}-7^{\circ} 50^{\prime}$ South Altitude and $104^{\circ} 48^{\prime}-108^{\circ} 48^{\prime}$ East Longitude. West Java borders Jakarta and Banten Province to the West, Central Java to the East, Java Sea to the North, and Indian Ocean to the South. In Topography, West Java has a characteristic as part of a volcanic belt with altitude of more than 1,500 meter above the sea level in the South, moderate hill with elevation of 100 to 1,500 meters. The climate of West Java Province is tropical, with average temperature about $17.4-30.7^{\circ} \mathrm{C}$ and humidity about $73-84 \%$. In 2014 , the highest rainfall occurred on March, which reached $418.7 \mathrm{~mm}$ and the lowest occurred on August, with $74 \mathrm{~mm}$. The average wind speed over the year 2014 reached 3.3 knots.

West Java Province has plantations that is managed of the State Owned Plantations or PTPN Estate (PBN) and Private Estate (PBS) and smallholder (PBR). Potential commodities are tea, coconut, oil palm, sugar cane and rubber plantations with a total area of 494,166 ha in the year 2013.

In 2013 especially for tea commodity, West Java mastered $78 \%$ tea plantations on Indonesia and $51 \%$ is tea smallholder plantations. From tea smallholder plantations has providing more than 79 thousands farmer households. In generally, the harvested area of tea plantation on West Java Province in 2013 is 94,391 ha, with a tea production of 113,885 tons, and tea productivity of 1.56 tons/ha which still less than 2 tons/ha also in tea smallholders only 1.3 tons/ha for tea productivity. Tea highest productivity achieved by the private estates followed by PTPN estates and the last was stallholders as the lowest productivity. During the years 2009-2013, the tea plantations of West Java Province experienced extensive development and production. Improved quality and production is one of the main goals of development of tea plantations, because tea plantations have a significant role in the tea national and its contribution to the GDP of West Java Province.

The result of Focus Group Discussion (FGD) showed that the education level of the most of tea smallholders are still low, i.e. only graduated from elementary school and their age are about 40-60 years old. From the age of 40-60 years old tea smallholder showed that tea smallholder in that condition still has a maturity physically and nonphysically allowing prima activity in carrying farm teas. Most of tea smallholders only have the average area of land owned tea is 0.78 ha. Most of the land ownership status 
of tea smallholders is property rights. The rest is state-owned land managed by the farmer during 25 years concession system.

Tea smallholders are actors who play role in the supply chain activities of tea cultivation, from the planting, maintenance and harvesting in the form of tea plucking. Most tea smallholders usually sell directly to traders that lived around the residence and the tea smallholder plantation and it was then taken to tea local factories where are not far from the location of tea smallholder plantation. A few tea smallholders sell the green leaf through tea farmer groups in which the group has to become agents of factory/tea entrepreneur in the tea collection if the location of factory is far from tea smallholder plantation. A few tea smallholders sell directly to tea factory because the location of the tea factory is near from tea smallholder plantation.

In general, the average of farm gate prices of green leaf are IDR.1,800/kg of fresh green leaf with no price differentiation based on the quality of green leaf farmers, while the ideal of farm gate prices is at least IDR 2,000 kg/fresh green leaf. Tea production activity is also not efficient because farmers only own tea land area below1ha. While ideally to manage of tea plantation need minimum of tha. The tea smallholder plantation are located in various places and still be managed individually. In addition, the limitations of the tea farmers' skills in maintaining and managing the business of tea gardens make the production of tea shoots farmers become quite efficient.

The role of tea farmer group which directly related to the supply chain such as units of production, collaboration and business has not fully run optimally. Most of the existence of the tea farmer groups over the course of collecting tea shoots but management has not run optimally to develop more commercial direction due to lack of management skills in marketing, management is further green leaf, and limited capital. Generally, tea farmer groups have shelters results facilitated by the government, but still not optimal in utilization and function.

The existence of farmer groups is also not quite been able to increase production and income of the group members. Production and income of tea smallholders are relatively fixed, not increase and decrease. However, the quality of bud continues to decline due to the rough plucking behaviour. The partnership developed largely undeveloped tea farmer groups towards the development of downstream because constrained by access to capital and technology. Figure 1. The existing structure condition on the supply chain collaboration green leaf farmer group which dominant.

However, from field showed that there are small farmer groups formed farmer group association to develop tea supply chain and increasing the added value of the product management of tea green leaf, so the selling price of tea green leaf higher. If tea green leaf managed by farmer groups and tea farmer association (called Gapoktan) the advantages are members can get the incentives for selling price of green leaf based on quality of green leaf. Through development of downstream products of green tea 


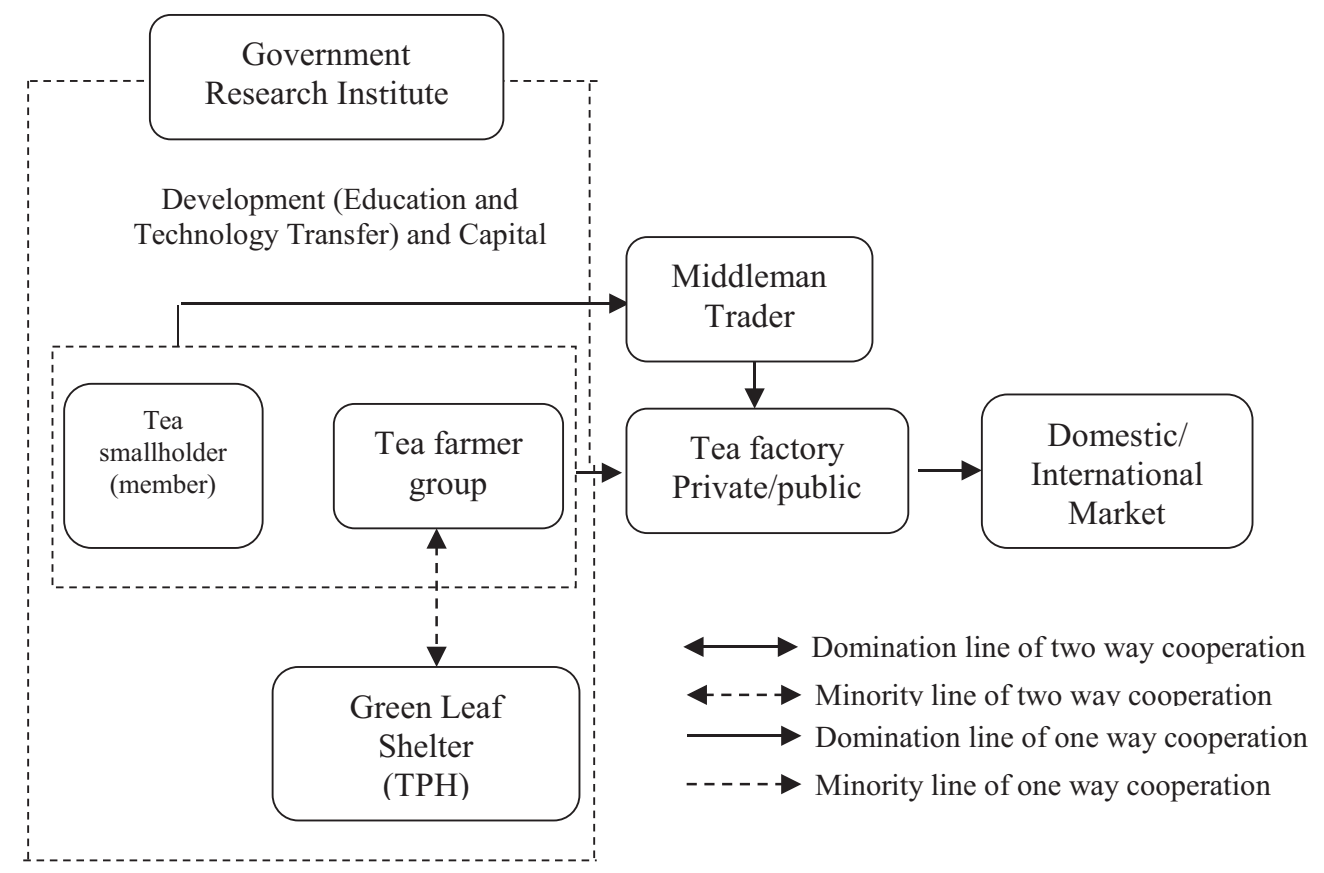

Figure 1: The existing structure condition on the supply chain collaboration green leaf farmer group which dominant.

and white tea, some farmers can enjoy better income. So the supply chain channel started from green leaf of members (tea smallholder) to the group to Gapoktan which has tea factory which facilitated the members of tea farmer group on tea production. Thus, farmers with the group and Gapoktan (association) will be able to improve its bargaining position. Here an in depth interview with the member of tea farmer group who have enjoyed a result of revenue stringed white tea and green tea.

"...since switching to pluck white tea, revenue has increased at least $150 \%$, of IDR. 240,000 to IDR. 900,000 per month and it is still not included by selling other shoots $(p+1, p+2, p+3)$ for green tea and black tea. If we sell other shoots (green leaf $p+1, p+2, p+3$ ) too, the revenue could be more than it...I am so glad...., hopefully other tea farmers may also want to follow me" (In depth interview with Mr. Acit, a member of Sugih Tani tea farmers group in Sukabumi District).

Based on in depth interview above, it can be concluded that an income of members (farmers) can be increased by diversifying production and sale of green leaf with sales of white tea buds. Gapoktan is also providing price incentive for member based on quality green leaf. The selling price of white tea buds by Gapoktan is IDR.200,000 per $\mathrm{kg}$ fresh peko leaf and green leaf out the top of the selling price or quotation plain white tea (smooth and medium plucking) is IDR.2,500 to IDR.5,000 per kg depend on the quality of which usually in sold at an average price IDR.1,800 per kg with no price differentiation of quality green leaf. 
Tea development potential of downstream business is very large and wide opened, given the potential market opportunities especially white tea and green tea are very open, as already shown from the results in the previous section. The selling price of premium white tea for the Japanese market is IDR. 1.2 to 1.7 million per kg. White tea market $(p+2)$ for the Swedish market amounted to IDR.300,000 per kg. Black tea selling price of IDR.75,000 per $\mathrm{kg}$. The magnitude of the potential markets for products downstream of tea farmers put forward by Mr.Ajat, Chairman of Gapoktan in Sukabumi.

"...With the help of the government in the form of white tea factory, Alhamdulillah, farmers are now introduced to a downstream product diversification tea, in addition to the income of farmers is also to be increased by plucking white tea, quality became more well-maintained gardens, because picking is done manually. For the market is not in doubt, very promising. Consumers still we had reached Sweden and China for these farmers tea products. Provided that the group would manage the results of the top farmers, God willing gardens will also be getting better, because it's different when farmers sell directly to the tea factory, there is no differentiation of the selling price where is rarely green leaf. Conversely, if the group becomes the collecttor also then group is responsible for the sustainable production of green leaf". (In depth interviews with Mr.Ajat, Chairman Gapoktan on February 27, 2015)

Currently, through Gapoktan, farmers' groups together formed a cooperative joint cooperation to address issues of capital which often becomes an obstacle to efforts to increase productivity and income of tea smallholders. Thus, institutional tea smallholders can be more robust and sustainable. Based on observations in the field, constraints experienced by farmers' groups is the weak management of cooperative institutions because of the low quality of human resources.

Availability of capital, technology, market information and access to qualified human resources has great momentum to meet the needs of others in the supply chain tea green leaf farmers in an effort to increase the income of tea smallholders. Thus, the availability of capital, technology, accessed to market information and quality human resources is the most preferred needs to be met in the supply chain collaboration tea green leaf. The fourth of these needs can be met if the supply chain involves institutions that have great momentum to provide capital, provide technology, provide access to market information, and improve the quality of human resources. For it is not only the government but also the involvement of banking institutions, research institutions /universities, NGOs/facilitators, and investors will be able to support the fulfilment of the main need cooperation in the tea downstream supply chain of tea smallholders. 


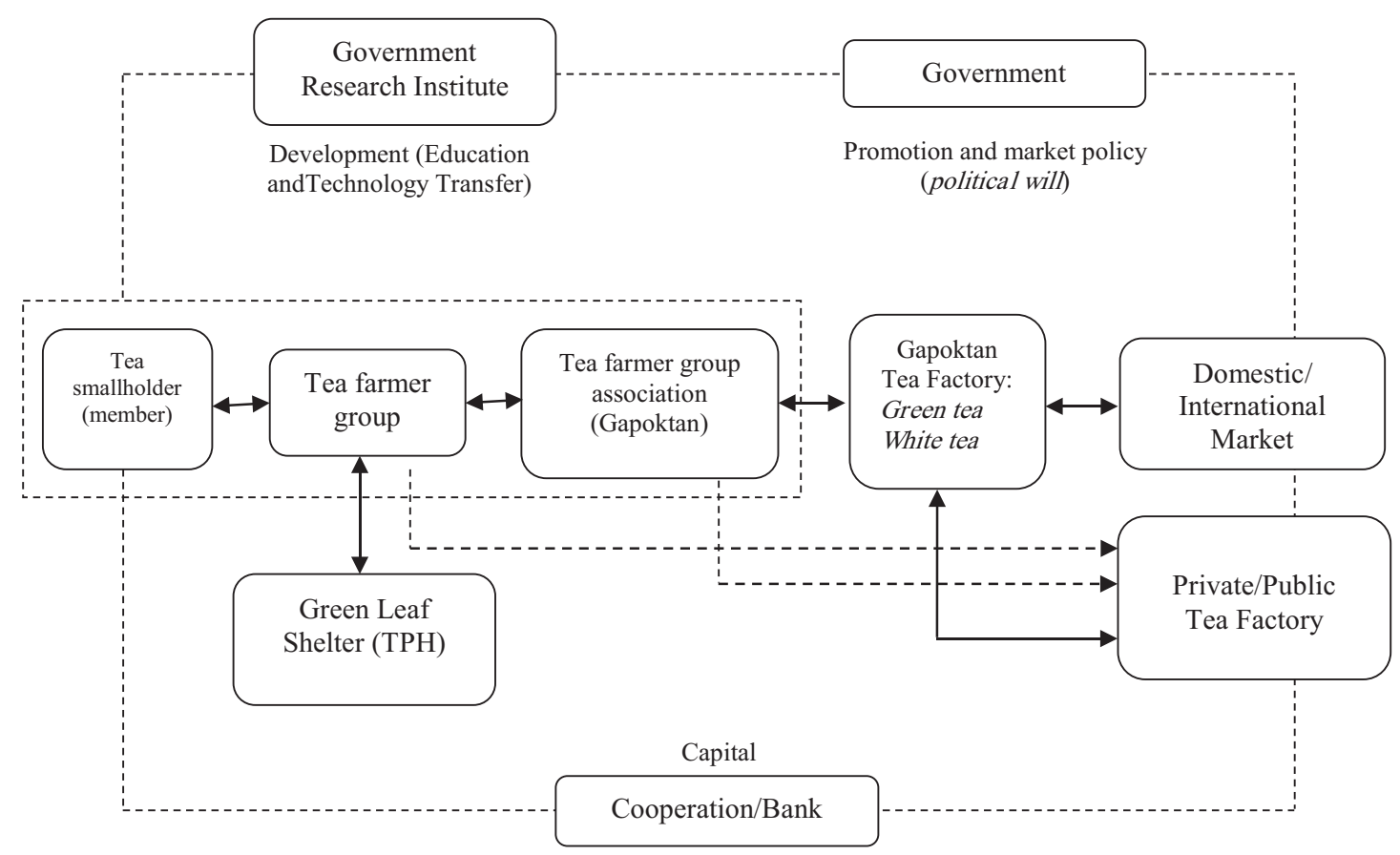

Figure 2: Prospects for development of tea downstream supply chain of tea farmer group.

Description of cooperation development to increase of technology transfer and cooperation of farmer groups in order to develop tea downstream supply chain prospective tea farmer groups in the future and can be seen in Figure 2. Prospects for development of tea downstream supply chain of tea farmer group.

The results from field also showed that most members (farmers) and tea farmer groups are very dependent on the existence of extension worker. Extension worker of plantation is regarded as expert power and informational power $[9,10]$ which position the extension worker to be the only source of information for the advancement of their tea farming. The existence of extension worker is helpful in making the tea farmer group in more dynamic activities. Extension is also an access to information for members (farmers) through tea farmer groups.

However, in reality the number of extension workers of plantation (tea) is not comparable with the area work of tea plantation, especially the field staff of the Department of Plantation. Most extension workers who are under extension board in district level or called by $\mathrm{BP}_{3} \mathrm{~K}$ rarely have the background estates, otherwise derived from food crops. This then becomes a problem for the majority of tea farmers' groups. Because of the lack of accessibility to education and extension mobility difficulties as a result of the physical condition and the extent of the target area farmer groups led to extension activities and assistance to the tea farmer groups become intensively and effectively carried out. The reality showed that there is ego sectoral reality on the ground remains the problem still exists. Coordination between $\mathrm{BP}_{3} \mathrm{~K}$, Plantation Office and other relevant agencies are still not running optimally. 
The role of education in fostering tea farmer groups is needed. Furthermore, counselling and assistance to farmers' groups need to involve many stakeholders. Previously, the institutional verification farmers (farmer groups) with commodity tea also very needed as a stage of institutional structuring tea smallholders which in turn helps in the smooth implementation and plantation development program. Additionally, good communication, coordination and cooperation among government agencies and other institution needs to be improved in order to minimize inter-agency ego sectoral.

In reality in the field, the market opportunities for tea smallholder is still small as indicated by still lacking impartiality policies are pro-farmers tea, still lack business development and product markets downstream of tea smallholder, plus limited information about market opportunities through counselling at the tea farmer group, In addition, most members (tea smallholders) directly sell its tea green leaf to the trade (middleman) or the factory and tea smallholder product generally still a fresh shoots which the value of the sale price or farm gate prices (IDR.1.800,-/kg) is still far from ideal selling price that can be benefit (IDR.2,500,-/kg). However, from this condition, making members individually or collectively with his group tries to create and innovate to create a market (created market) through the development of technology development of downstream simple (traditional) in accordance with the local wisdom in the region whose purpose is to provide added value from tea green leaf members (farmers) in order to raise revenue from tea farming.

The examples diversified development of downstream products of tea smallholders using simple technology is tea bracelets, green tea, powdered green tea, green tea, chocolate, tea kapol (variants of tea with cardamom), tea katuk (tea variants with Katuk), ginger tea (tea variants with ginger). Examples diversified development of downstream products of farmers using more modern technology is white tea and black tea. The market of tea smallholder product is not only local and national but has penetrated overseas market (Malaysia, Japan, China, Sweden). It also cannot be separated from the use of internet media and social media (Facebook, blogs, Twitter). This is the end that led to large the downstream supply chain of tea smallholder product grow and develop.

\section{Conclusion}

Increasing the role of farmer groups by the major actors (members) and other actors (tea stakeholders), especially as a medium for cooperative, collaboration and effort on development and support tea downstream supply chain of tea smallholder needs to be improved. Tea downstream supply chain cooperation which needs to be improved related to business development and cooperation with other parties (cooperatives, banks, state and private plantation companies, research institutes and universities). 
Increased efforts need to be improved, especially the downstream business of tea, the tea business outside the farm, and business groups.

The availability of capital, technology, accessed to market information and quality human resources on tea smallholder plantation is the most preferred needs to be met in the supply chain collaboration tea green leaf. For it is not only the government but also the involvement of banking institutions, research institutions /universities, NGOs/facilitators, and investors will be able to support the fulfilment of the main need cooperation in the tea downstream supply chain of tea smallholders.

The efforts to increase the role of farmer groups on downstream supply chain also through the increasing of the extension and education for tea smallholders through the strengthening tea farmer group. The role of chairman of the tea farmer group who has leadership (leadership) can encourage farmer groups to become more dynamic and effective in carrying out its farmer group function on production, cooperation and business.

The strengthening of tea farmer group through improved performance coaching and counselling farmer groups by the extension agents in the form of education, training, experimentation, and ongoing assistance, especially with regard to the application of cultivation technologies, development of marketing and business development downstream of tea. Coaching and mentoring to farmers' groups should also be advised on the growth and development of cooperation between members and between groups of farmers tea (main actors) as well as partnerships with businesses tea in the framework of marketing and business development activities downstream of tea.

\section{Acknowledgments}

The author gratefully thank to Graduate School of Gadjah Mada University and Extension and Communication Development Program Study that has given opportunity for author to study here. Also gratefully thank to my supervisors Prof. Sunarru Samsi Hariadi and Subejo, SP., M.Sc., Ph.D that greatly supported during the study. The author gratefully thank to Research Institute for Tea and Cinchona, Indonesia who has facilitated this research and also to Dr. A. Imron Rosyadi for great discussion. The author thank to Tri Maruto Aji, SP., M.Sc. and extension workers in field who assisted and facilitated in data collection. Gratefully thank to tea farmers for share the great experiences about tea farming and tea institution. The author also thank to reviewers for their so called-insight. 


\section{References}

[1] EIU. (2015). EIU Global Forecasting Service:Tea. http://www.gfs.eiu.com. Accesssed on 15 August 2015.

[2] Balai Penelitian Tanaman Industri dan Penyegar (Balittri). 2014. Perkembangan Pasar Teh Indonesia di Pasar Domestik dan Pasar Internasional. http://balittri.litbang.pertanian.go.id/index.php/berita/207-perkembangan-pasarteh-indonesia-di-pasar-domestik-dan-pasar-internasional

[3] Slamet, M. (2001). Perspektif Ilmu Penyuluhan Pembangunan Menyongsong Era Tinggal Landas dalam Penyuluhan Pembangunan di Indonesia: Menyongsong Abad 21.PT Pustaka Pembangunan Swadaya Nusantara. Jakarta.

[4] MoA. 2007. Peraturan Menteri Pertanian No. 273 Tahun 2007 tentang Pedoman Pembinaan Kelembagaan Petani. http://perundangan.pertanian.go.id/admin/file/SK-27307.pdf.

[5] Hariadi, S.S. 2011. Dinamika Kelompok: Teori dan Aplikasinya untuk Analisis KeberhasiIan Kelompok Tani sebagai Unit Belajar, Kerjasama, Produksi, dan Bisnis. Yogyakarta: Sekolah Pascasarjana Universitas Gadjah Mada.

[6] Silverman, D. (Ed.). (2010). Qualitative research. Sage.

[7] Miles, M. B., \& Huberman, A. M. (1994). Qualitative data analysis: An expanded sourcebook. Sage.

[8] Moleong, J. Lexy. (2007) Metodologi Penelitian Kualitatif. Bandung, PT. Remaja Rosdakarya.

[9] Umstot, D.D. 1988. Understanding Organizational Behavior. Second Edition. United State of America: West Publishing Company.

[10] Gibson, J.L., J. M. Ivancevich, J. H. Donelly, Jr., and R. Konopaske. 2009. Organizations: Behovior, Structure, Processes. Fourteenth Edition. New York: The McGraw-Hill Companies, Inc. 